\title{
Velkommen til Tidsskrift for Professionsstudier nr. 23
}

Dette nummer af Tidsskrift for Professionsstudier tematiserer etnografiske studier og forskningsbaseret evaluering af uddannelsesprojekter i skolastiske, professionsorienterede og akademiske læringskontekster. De gennemgående problemstillinger knytter sig til kortlægning af organisations- og pædagogikudvikling, komparative studier i de skolastiske og kliniske kontekster samt undersøgelser af læringsstrategier og kompetenceudvikling. Med skiftende vægt er udgangspunktet innovationer i de sundheds-, samfunds- og humaniorafaglige uddannelser med casestudier $\mathrm{i}$ skolen og i de gymnasiale uddannelser, universitets- og professionsuddannelser. I casestudierne er der således arbejdet organisations- og skolekonkret både med interprofessionalitet og med professionsnære og digitale udviklingsstrategier, online-læring og e-pædagogik. Gennem de igangværende feltarbejder og casestudier identificeres læringskontekster og deres relationer til teori og begreber om hhv. skolastisk læring og læring gennem deltagelse i den professionelle praksis. Såvel i udviklingen af de etnografiske metoder som i udviklingen af de teoretiske koncepter er udfordringen indrammet af dette spændingsfelt mellem formel skolastisk læring og uformel praksis- og professionslæring. Analysestrategisk er udfordringen indrammet af spændingsfeltet mellem de innovative projekters intentioner, mål og visioner og de faktiske betingelser.

I temanummeret lægges der vægt på at give overblik og analyser af uddannelsesprojekterne og de karakteristiske træk ved deres implementering, forløb og resultater. Samtidig er det muligt at gå på tværs af de enkelte casestudier og sammenfatte fælles temaer og problemstillinger. Herigennem identificeres de aktuelle dilemmaer og udfordringer på henholdsvis policy-niveauer og uddannelsespraktiske niveauer. Desuden præciseres forbindelser mellem det innovative projekt og de organisatoriske træk og udviklingsstrategier. Som det vil fremgå gør projekterne dette: 'at trække forbindelsen mellem innovation i organisation og uddannelse' til deres kendemærke. Herved knyttes interventionen og dens læringsværdier konkret til den organisatoriske og uddannelsespraktiske kontekst. For de etnografiske studier er denne praktiske kontekstualisering udgangspunkt og ledetråd; både for udforskning af den uddannelsespolitiske og pædagogiskpraktiske kontekst.

\section{Den politiske diskurs} og kravet om innovation Konfronteret med krav om styrkelse af innovative projekter og innovative kompetencer lægger forskningsgruppens projekter op til en forståelse af disse krav som en del af den politiske diskurs. Men 
Tema: Innovation og uddannelse

samtidig skal uddannelsessektorens 'egne' betingelser og innovationsbegreber forstås. Som det fremgår af temanummerets artikler spænder innovationsbegrebet derfor vidt og refererer såvel til policyniveauer som uddannelsesniveauer, såvel til det innovative projekts produkt som til implementeringsprocessen. Som begreb (om krav om professions- og kompetenceudvikling) kan de innovative kompetencer forstås i slægtskab med den kvalifikationsteoriske opfattelse af innovative kvalifikationer som almene, grundlæggende kvalifikationer og som videnskabelige kvalifikationer. I temanummeret betoner sådanne grundlæggende definitioner et fælles udgangspunkt, som dernæst specificeres af den aktuelle kvalifikations- og professionsforskning og af den praktiske kontekst. Det er fx vigtigt for forståelsen af et interprofessionelt projekt som Projekt InterTværs, at man beskriver det generelle krav om innovative kvalifikationer som et krav, der stilles såvel til sundhedsfagenes læger, sygeplejersker, ergo-fysioterapeuter som til de samarbejdende team. Det generelle krav handler om innovation og fornyelse af professionernes vidensbase samt om at indgå i vidensudvikling og -anvendelse og her demonstrere, at fagenes udøvere og professionelle har del i de innovative kvalifikationer og projekter. Desuden er kravet om deltage i innovations-, udviklings- og forskningsarbejde understreget politisk og officielt, som det aktuelt tydeliggøres i revisioner af professionsbacheloruddannelserne. I den forstand vidner den politiske diskurs stedse om, at kravet om innovation er integreret i policy-niveauets reformer og programmer, samt at det dernæst skal have konsekvenser for uddannelsesniveauets projekter. Analysen af de innovative projekters praktiske betydning skærpes herefter ved at fastholde de kontekstnære fortolkninger af innovation.

\section{Med udgangspunkt i \\ det innovative projekt}

Temanummerets analyser vidner om et projekt- og kontekstnært udgangspunkt for begreber og refleksioner over, hvad innovation er og betyder. I artiklen Innovation - i lcerernes optik viser Nina Holst Waaddegaard på baggrund af casestudier i folkeskolen, hvordan lærerne i transformationsprocessen gør innovation til et spørgsmål om 'metode' og 'projektmodel' (kaldet ISI-modellen). I artiklen Når det innovative projekt er at gøre skolen til en hverdagsaktivitet - om skoleudvikling i Nordghana af Line Agerlin Trolle refererer det innovative projekt til et helskoleperspektiv og til en innovativ praksis. Det at skabe kvalitet i uddannelse og holde skole i denne lokale kontekst handler om at initiere en ny tradition for uddannelse. Den karakteristiske kontekstspecifikation fastholdes som drivkraft også i relation til undersøgelser af innovative kvalifikationer som lærerkvalifikationer, som det vises i henholdsvis Louise Klinges artikel Lœrerens relationskompetence er en nødvendig innovativ kompetence og Clemens Wiesers artikel Continuing innovation and development of teacher expertise - the continual transformation of personal knowledge for teaching. Idet der sættes fokus på læreres kompetenceudvikling, integreres de innovative kvalifikationer i lærernes praktiske kompetence-reservoir. I udvikling af lærerekspertise gennem praksisviden, som Wieser fokuserer på, og i udvikling af lærerens relationskompetence, som Klinge fokuserer på, understreges tillige, at de innovative kompetencer berører såvel lærerens personlige udvikling som udviklingen af undervisningen og klassens læringsfællesskab. At der heri ligger en interesseforskydning, således at hele den pædagogiske og organisatoriske kontekst står i centrum, bekræftes også af de projekter og feltarbejder, der som følgeforskning gennemføres i professionsuddannelsernes grund- og efter-videreuddannelser. Med et skærpet blik på organisations- og ledelsesniveauet reflekterer Roddy Walker i artiklen "Investigating the influence of a leadership development programme" de etnografiske tilgange til spørgsmålet om kompetence- og ledelsesudvikling $\mathrm{i}$ pædagogiske institutioner.

Med et skærpet blik for innovative projekter som hele og samlede forløb (fuldskala-projekterne) kan følgeforskningen fastholde både den fælles platform, de specifikke formninger og de begrebslige og paradigmatiske udfordringer, der måtte gå på tværs af casene. Fx fremgår det af analyser på tværs af projekter i den professionsorienterede læringskontekst, at de for at bidrage innovativt udfordres til et paradigmeskifte og til en kritik af det aktuelt dominerende læringsparadigme. I pædagogiske vendinger betyder det, at de innovative uddannelsesprojekter udfordres til at nytænke principper om studenteraktiverende læringsformer og om problem- og projektbaseret læring. 
Herigennem præges de innovative uddannelsesprojekter af stadig virksomme relationer til casepædagogikken og det projektpædagogiske paradigme med rødder i 1970'erne, samtidig med at læringsmålstyring og det aktuelle erhvervs- og samfundsorienterede paradigme sætter tydelige præg på de innovative uddannelsesprojekters gennemførelse. I artiklen Alternative rum til lœring? analyserer Anita Lyngsø og Camilla Kirketerp Nielsen online- og spilbaseret læring på sygeplejeuddannelsen og dyrlægeuddannelsen. Det vises, hvordan de alternative læringsrum producerer nye strategier og muligheder, men samtidig reproduceres strategier kendt fra de traditionelle læringsrum. I den forstand risikerer innovationen at blive 'skolificeret', samtidig med at det innovative projekt peger fremad mod praktisk styrkelse af professionsorienteret læring.

\section{Styrkelse af det}

\section{professionsorienterede uddannelser} Idet projekterne selv deltager i en styrkelse af den professionsorienterede innovation, er det for professionsbacheloruddannelsernes vedkommende internt markeret af igangværende revisioner. Eksternt er de innovative projekter markeret af bestræbelser om styrket interprofessionalitet og med større nærhed til hhv. patienter, borgere og brugere af hhv. sundheds- og skolevæsenet. I artiklen Projekt InterTvœrs og interprofessionalitet som det innovative match analyserer Cathrine Sand Nielsen og Tina Kramer uddannelsesprojektet InterTværs som et bud på fremtidens velfærdsuddannelser, og som et svar på omverdenens krav om sammenhængende patient-/borgerforløb. I artiklen Digital kompetence som en del af lœgestuderendes professionelle udvikling fastholder Dorthe Furstrand og Lars Kayser, hvordan krav til innovative og digitale kompetencer rettes mod lægegerningen og professionsrollen i den samlede lægefaglige kontekst og derfor også skal beskrives i snitfladen mellem samfundsmæssige behov, politiske krav og sundhedssektorens udfordringer. På denne baggrund viser caseanalyserne, hvordan de sundhedsfaglige uddannelser og krav til fremtidens mono-faglige og interprofessionelle kompetencer bevæger sig ud over og væk fra den traditionelle kerne i sundhedsuddannelserne. Gennem uddannelsescasene på det sundhedsfaglige område sættes der fokus på de aktuelle udfordringer, som krav om innovative kompetencer, digitale kompetencer og kravet om interprofessionalitet sætter på dagsordenen. Historikken bag indrammer Raymond Kolbæk i artiklen IT-innovationer fra kontorlandskaber til lœringslandskaber. Baseret på empiriske studier af it-innovationer i sygeplejefeltet, analyseres karakteristiske udviklingstræk og konsekvenser for perioden 1950'erne og frem til i dag. Analysen viser bevægelsen, hvor computere startede som en innovation i kontorlandskaberne over skolebibliotekerne for senere at ende i læringslandskaberne. Samtidig inddrages sundhedssektoren som den omkringliggende kontekst. Herigennem vises udviklingsdynamikken som it-innovationer, der gør computere til netværk og portaler, men også som uddannelsespolitiske tiltag, der gør feltet og uddannelsesforløb til digitale kredsløb. Det aktuelle fokus ‘hele det digitale kredsløb’ præciseres afslutningsvist af Catarina Player-Koro $\mathrm{i}$ artiklen The contemporary faith in educational technology - a critical perspective. På baggrund af empiriske studier sætter Player-Koro fokus på modsætninger mellem den optimistiske tro på udvikling af uddannelse gennem implementering af teknologi og de aktuelle realiteter i brugen af teknologi. I så henseende indrammes den kritiske analyse af de aktuelle tendenser, men også af et dilemma, hvor bevæggrunde for it \& læring veksler mellem det digitale kredsløbs politisk-økonomiske og pædagogiske begrundelser. På denne baggrund er de innovative uddannelsesprojekter udfordret. Samtidig er projekterne selv aktive deltagere i det digitale kredsløb og hermed udfordret i praktisk forstand, Som det fremgår af temanummeret betyder det, at de innovative projekter er udfordret til at navigere i kredsløbet, skærpe de pædagogiske begrundelser og til at udøve praktisk kritik.

Temanummeret er blevet til i samarbejde med forskningsgruppen Etnografiske Studier i Innovative Lœringskontekster på Københavns Universitet. Gruppen gennemfører casestudier og forskningsbaseret evaluering af innovative uddannelsesprojekter i skolastiske, professionsorienterede og akademiske læringskontekster.

Velkommen til Tidsskrift for Professionsstudier \#23 